Instructions for authors, subscriptions and further details:

http://brac.hipatiapress.com

\title{
Eureka! Panoramic Festival or the creative relationship between photography and cinema
}

Natàlia Lloreta Pané ${ }^{1}$

1) Universitat Pompeu Fabra (Spain)

Date of publication: October $3^{\text {rd }}, 2018$

Edition period: October 2018 - February 2019

To cite this article: Lloreta, N. (2018). Eureka! Panoramic Festival or the creative relationship between photography and cinema. Barcelona, Research, Art, Creation, 6(3) 350-354. doi: 10.17583/brac.2018.3431

To link this article: http://dx.doi.org/10.17583/brac.2018.3431

\section{PLEASE SCROLL DOWN FOR ARTICLE}

The terms and conditions of use are related to the Open Journal System and to Creative Commons Attribution License (CC-BY). 
BRAC - Barcelona Research Art Creation. Vol. 6 No. 3, October 2018, pp. 350-354

(Recibido: 11 abril 2018; Aceptado: 18 junio 2018; Publicado: 3 octubre 2018)

\section{Review}

\section{Eureka! Panoramic Festival or the creative relationship between photography and cinema}

In our western collective imagination, we live on this romantic idea that the great inventions of humanity are a result of a moment of divine inspiration that makes the eureka echo throughout seas, mountains and valleys. And maybe it's not like that. That moment of putting into practice that longed invention, that ingenious idea, that moment in which everything works must be wonderful, almost magical, but above all the sensation must be like that of those who conquer the top of a mountain: yes, finally!

With photography and cinema something like that may had happened. The technical and social advances -in the first third of the 19th century in the case of photography, and at the end of the same century, in the case of cinema had left everything ready and worked so that stubborn and hard-working minds found the right way to make this latent demand come true. That is why the creators of each invention -or each discovery- are not univocal and indisputable. The merit of having invented photography is attributed to the French Joseph-Nicephore Niepce, who in 1826 managed to print a view from the window of his room in a physical medium, after more than 8 hours of exposure. But it is Louis Daguerre who spreads it and popularizes it in a commercial way with the mythical daguerreotype; and the English have their particular claim with William Fox Talbot's calotype. Most unanimous is the granting of the title of cinema inventors to the Lumiere brothers, Auguste and Louis, even though the United States claims the podium to the inventor Thomas Alva Edison.

In any case, these pioneers or others would have provided the solutions to the great social needs of the nineteenth century bourgeoisie, photography and cinema, which today have become indispensable heritage of humanity.

Photography and cinema are inseparable disciplines, although each one holds a very unique language, style and technique. And it is striking that in the $21^{\text {st }}$ century, with such a never-ending proliferation of cultural 
manifestations and festivals, there was still not one to deal with both at the same time. It is Panoramic Festival, whose first edition took place in Granollers from November 21st to December 11th, 2017, the one that undoubtedly holds the authorship of this proposal. Eureka!

The Panoramic project starts as an initiative of Albert Gusi and Fidel Balaguer, responsible for Grisart, and has the support of Joan Fontcuberta, the complicity of Jesús Vilamajó and the curatorship of Fèlix Pérez-Hita and Andrés Hispano (authors of the must SoyCámara), Laia Casanova and Joana Hurtado. It receives the institutional and financial support of the City Council of Granollers and of the Government of Catalonia.

Thematically, this first edition of the festival has been devoted to the film stills - or the promotional image of a film, which, despite being born as a support format for cinema has had a great influence on contemporary art- and it is has been structured in three areas: screenings, exhibitions and workshops, always giving space to both consolidated artistic proposals and emerging voices.

The screening sessions of the festival featured a succulent program of feature films and short films, including, among others, the legendary La Jetée by Chris Marker, a 28-minute photo-story from 1962 that, through several photos -all of them of intense monochromatic beauty- narrates a dystopia about memoirs and journeys through time; the masterful Ilha das Flores, a 13minute short film, directed by Brazilian Jorge Furtado in 1989, who punishably criticizes capitalism and consumerism based on intelligence and sense of humor; and the very short film by the creative beast David Lynch Premonitions Following an Evil Deed, which with 52 seconds shows 5 scenes after a murder. The screenings were also complemented by La Porxada Doc, which grouped documentary emerging authors of the territory.

In the field of exhibitions, Panoramic programmed Mites i Màscares (Myths and Masks), which showed the creative worlds of filmmaker Albert Serra and photographer Román Yñán; and La Tèrmica $L A B$ - "the expanded part of the festival", called so by the same organizers- a collective exhibition born from an open call to promote the work of artists using new media. The exhibition was held in the tèrmica space, the machine room of the former Roca Umbert cotton mill in Granollers, a space with strong power of attraction per $s e$ that was intensified thanks to the works of the 15 selected artists.

The intense relationship between photography and cinema provides a multitude of suggestive, interesting and inspiring themes that, if the complicity with the public administrations and its financial support continues, the Panoramic Festival is guaranteed for many editions. 


\section{Eureka! Festival Panoràmic o la relació creativa entre fotografia i cinema}

En aquest nostre imaginari occidental, vivim de la idea romàntica que els grans invents de la humanitat són fruit d'un moment d'inspiració divina que fa retronar l'eureka per mars, muntanyes i valls. I potser no és així. Arribat el moment de posar en pràctica l'anhelat invent, l'enginyosa idea, aquell moment en què tot funciona deu ser meravellós, quasi màgic, però sobretot la sensació deu ser com aquella que tenen els qui coronen un 8.000: ja era hora!

Amb la fotografia i el cinema devia passar una mica això. Els avenços tècnics i socials, tant al primer terç del s. XIX pel cas de la fotografia, com a finals del mateix segle, en el cas del cinema, ho havien deixat tot preparat $\mathrm{i}$ llaurat perquè una ment obstinada i treballadora trobés la manera adequada de fer realitat aquesta demanda latent. És per això que els artífexs de cada invent -o de cada descobriment- no són unívocs i indiscutibles. S'atribueix el mèrit d'haver inventat la fotografia al francès Joseph-Nicephore Niepce, qui l'any 1826 va aconseguir imprimir una vista des de la finestra de casa seva en un suport físic, després de més de 8 hores d'exposició. Però és Louis Daguerre qui la difon i popularitza de manera comercial amb el mític daguerreotip; i els anglesos tenen la seva pròpia reivindicació amb el calotip de William Fox Talbot. Més unànime és l'atorgament del títol d'inventors del cinema als germans Auguste i Louis Lumiere tot i que els Estats Units reclamen el podi a l'inventor Thomas Alva Edison.

En qualsevol cas, aquests pioners o uns altres haurien proporcionat les solucions a unes grans necessitats socials de la burgesia del s. XIX, la fotografia i el cinema, que avui han esdevingut patrimoni irrenunciable de la humanitat.

Fotografia i cinema són disciplines indissociables si bé cada una conserva un llenguatge, un estil i una tècnica molt pròpies. I és sorprenent que en ple s. XXI, amb la proliferació incansable de manifestacions culturals i festivals, encara no n'hi hagués cap que parlés de totes dues a la vegada. Ha estat el Festival Panoràmic, la primera edició del qual ha tingut lloc a la fàbrica Roca Umbert de Granollers del 21 de novembre a 1'11 de desembre de 2017, qui, indiscutiblement s'atorga l'autoria d'aquesta proposta. Eureka!

El projecte Panoràmic neix de la iniciativa d'Albert Gusi i Fidel Balaguer -responsables de Grisart- i compta amb l'apadrinament de Joan Fontcuberta, la complicitat de Jesús Vilamajó i el comissariat de Fèlix Pérez-Hita i Andrés Hispano (artífex de l'imprescindible SoyCámara), Laia Casanova i Joana 
Hurtado. Rep el suport institucional i financer de l'Ajuntament de Granollers i de la de Generalitat de Catalunya.

Temàticament, aquesta primera edició del festival s'ha dedicat al film still -foto fixa o imatge promocional d'una pel·lícula, que malgrat néixer com a format de suport al cinema ha tingut una gran influència en l'art contemporani- i s'ha estructurat en tres potes: projeccions, exposicions $i$ tallers donant sempre espai tant a propostes artístiques consolidades com a veus més emergents.

Les sessions de projecció del festival han comptat amb una suculent programació de llargmetratges i de curtmetratges, entre els quals, la mítica $L a$ Jetée de Chris Marker, fotonovel-la de 28 minuts realitzada el 1962 que mitjançant diverses fotos fixes -totes d'una intensa bellesa monocromàticanarra una distòpia sobre la memòria i el viatge en el temps; la magistral Ilha das Flores, de 13 minuts de durada realitzada pel brasiler Jorge Furtado l'any 1989, que critica punyentment el capitalisme i el consumisme a partir de la intel-ligència $i$ el sentit de l'humor; $i$ el curtíssim curtmetratge de la bèstia creadora David Lynch Premonitions Following an Evil Deed, que amb 52 segons mostra 5 escenes posteriors a un assassinat. Les projeccions s'han complementat també amb la proposta La Porxada Doc, que ha agrupat autors documentalistes del territori.

La intensa relació entre fotografia i cinema proporciona multitud de temes suggeridors, interessants i inspiradors que, si es revalida la complicitat amb les administracions públiques, garanteixen Festival Panoràmic per moltes edicions. 
Natàlia Lloreta Pané

Email address: natalloreta@gmail.com

Web: www.1loreta.org 